\title{
PREPARING SUSTAINABLE SCHOOL-TEACHERS TOWARD ONLINE LEARNING THROUGH HOT POTATO QUIZ-MAKER MEDIATED INSTRUCTION: A COMMUNITY SERVICE PROGRAM
}

\author{
$\operatorname{Misdi}^{*}$ \\ Siti Aisyah ${ }^{2}$ \\ Rina Destiana ${ }^{3}$ \\ Nurani Hartini ${ }^{4}$
}

1,2,3,4Universitas Swadaya Gunung Jati, Cirebon, Indonesia

$\underline{\text { misdirina@gmail.com }}^{1^{*}}$

Keywords: [Hot potato, Junior high school,

Teachers, Quiz,

Professionalism]

\begin{abstract}
Professional Content Knowledge of Indonesian junior high school teachers are truly challenged during the Covid-19 Pandemic. To overcome these limitations, this community program aims to empower junior high school teachers, especially at SMPN 1 Kedawung in designing online learning through the platforms of google and potato quiz makers. Workshop was designed to help overcoming the situation. Fifteen recommended teachers participated in the workshop. From the observation and questionnaire analysis, the results showed teachers' instructional improvement in handling and designing online assessment and evaluation throughout hot potato quizzes and google-supported application.
\end{abstract}

\section{Introduction}

SMPN 1 Kedawung is located at Jalan Cideng Jaya, No. 299, Kertawinangun Village, Cirebon Regency-a school in the middle of the village that is mostly farming and trading are easily found around. In this environment, a small percentage people work as employees or civil servants. This school runs a plenty of intra and extracurricular activities. The profile of SMPN 1 Kedawung can be seen in the following image.

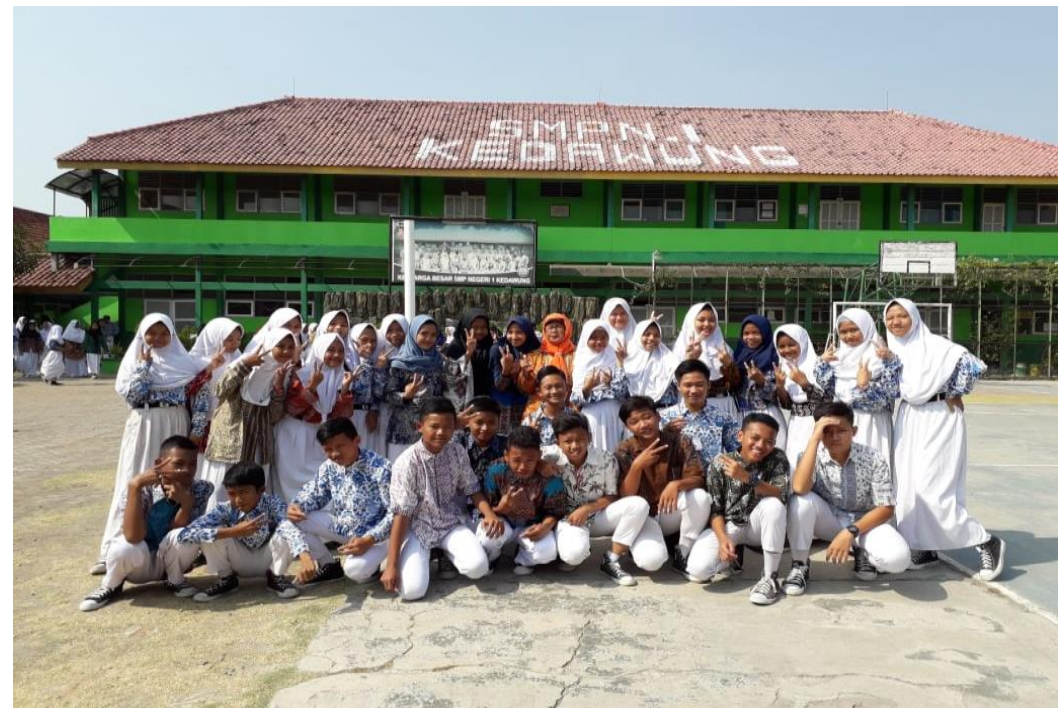

The Covid-19 pandemic has changed the face-to-face meeting in SMPN 1 Kedawung. Learning activities that are easily carried out face-to-face, has changed 
drastically. Now, teachers become new learners. They face a situation that previously unpredicted. Teachers adapt naturally to survive in learning. Within limitations, learning activities run with varieties of remote assignment system. The available learning systems and application are presented in the following table.

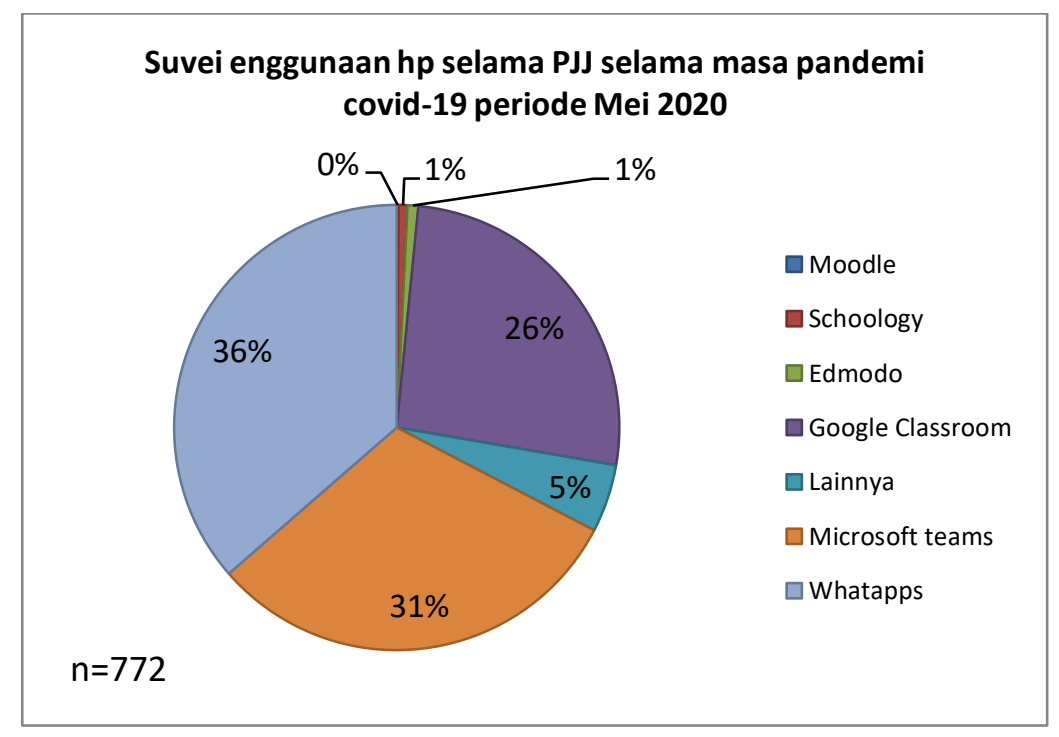

Author survey results at schools in Cirebon in May 2020

The data came from 772 responses their instructional practices conducted through google form since may 2020 as pandemics spread out. These data came from a number of schools in Cirebon District including SMPN 1 Kedawung. The results of the survey found that the use of WhatsApp is still dominant during online learning activities. a concern was made about the use of mobile phones or smartphones as a medium or learning tool as reported in (Aisyah, S., Danumihardja, M., \& Misdi, M., 2020; Misdi, M., 2020; Misdi, N., Kusriandi, W., \& Tambunan, A. R. S., 2020).

After observation to the school, the conditions confirmed if the literacy of instructional technology of teachers required improvement. WA group is still recommended as an instructional medium during the Covid-19 pandemic. These practices have impacted students in their learning. This is as shown in a screenshot of one of the teachers' instructional activities at the school.

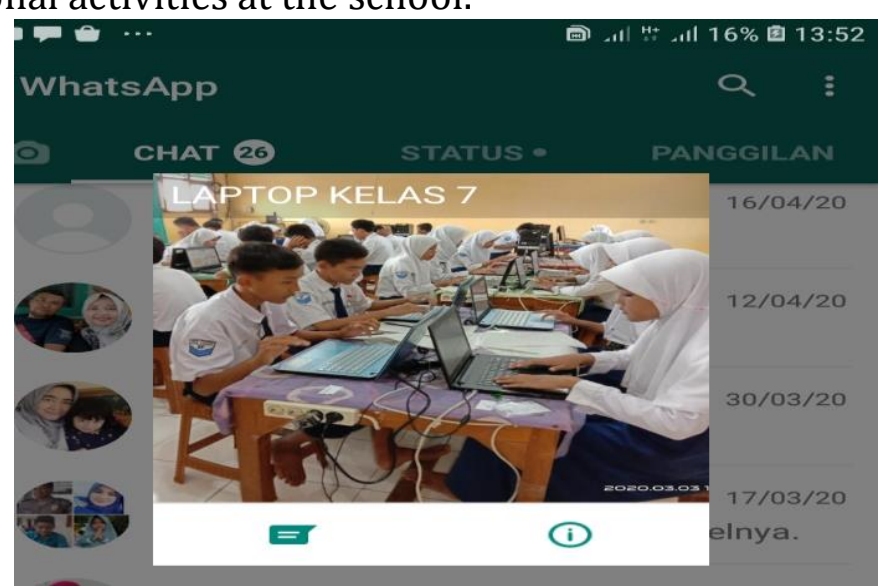

Figure 2. WhatsApp group becomes the main instructional media for teachers 
From observations, surveys, and interviews, the teachers at SMPN 1 Kedawung experienced not only in the online class but also students' tasks assignment and exercises. These barriers and challenges were identified in the following findings.

1. Low instructional technology literacy skills of teachers

2. Lack of ability to design distant learning

3. Teachers tend to burden students with assignments rather than providing discussion activities or more student-friendly tasks.

4. Monotonous assignment tend to demotivate students

5. Finally, long-distance learning activities are potentially ineffective and inefficient.

After identifying potential and causes of the above conditions, determined priority program was designed to overcome the barriers and took positive points for the challenges. The designed-based program was promoted using (1) Hp android, and (2) Potato quiz maker. Android phones were adopted and designed for providing positive impact for students' motivation (Aisyah, S., Danumihardja, M., \& Misdi, M., 2020), as well as e-portfolio tailored assessment (Misdi, M., 2020). With these main functions, online learning activities will be hopefully improved for its efficiency and effectiveness.

In addition, the adoption of android and online quiz can help increasing the participation of teachers and parents in learning because the contributions of each of these can empower both teachers and parents (Misdi, N., Kusriandi, W., \& Tambunan, A. R. S., 2020; Destiana, R., 2020). Online accessed mobile-phone instruction linked teachers and students to make learning easier and effective. Thus, teachers can create a more interesting distance learning. This is to say, a more student-centeredness. Moreover, teachers are more creative to innovate.

\section{Methods}

The methods offered workshops and assistances in implementing the use of android and potato quiz maker in advanced. The current community services limit to workshops. For this workshop, a school auditorium became the venue of the workshop. This workshop was held on Tuesday, March 16, 2021 at 09.00 to $12.00 \mathrm{pm}$. In this workshop, two speakers / facilitators were invited to share and provide the teachers course of educational technology. In addition to this, learning tips psychology classes was also given from the Institute for Community Service team, University of Swadaya Gunung Jati Cirebon.

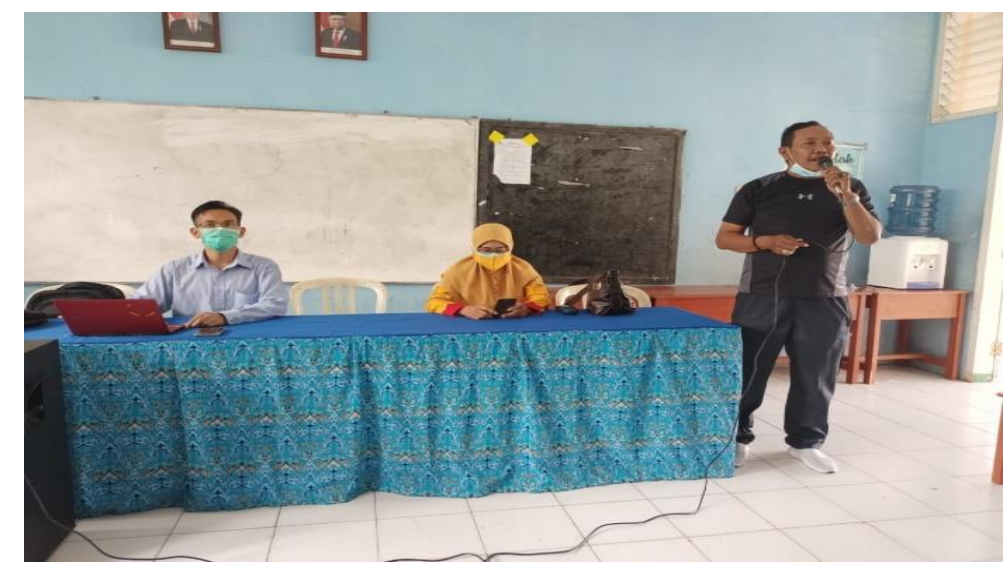

Figure 3. The opening of the workshop 


\section{Participants and parameter}

The participants were teachers in SMPN 1 Kedawung Cirebon who were assigned by the principal. Fifteen teachers participated in the workshop. In terms of evaluation, to know the success of seminar activities and their impact on teachers' understanding of the educational technology literacy, direct observation during the workshop and questionnaire were distributed as the activity ends. The results of observations and questionnaires were proceed and analyzed in Microsoft Excel and presented in tables and images. Descriptive analysis was adopted to interpret these results.

\section{Result and Discussion}

\section{Teachers' literacy on educational technology}

The seminar was piloted from google application and potato quiz maker. The results of the analysis and interpretation of data show active participation and enthusiasm of participants. This is also seen from the results of the questionnaire returned by the participants. The findings show positive improvement of the promoted application-management skills and their good impression toward their professionalism development as seen from the following chart.

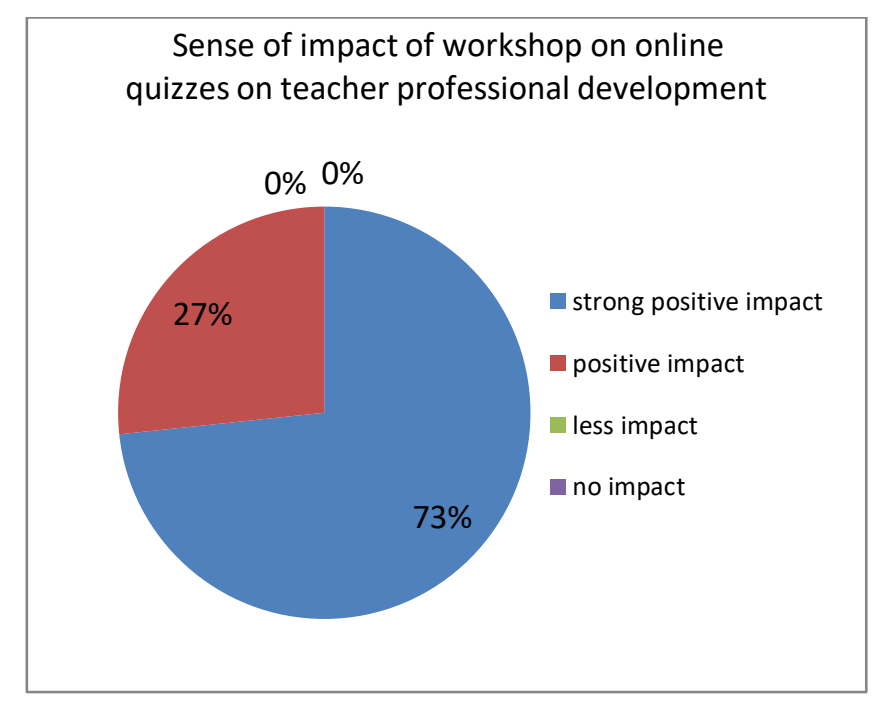

Chart 1. Sense of professional improvement in using the application

Seventy-three percents of the respondents felt said their professionalism in using the google form and google classroom getting improved. They also said this was the first time using and practicing the hot potato quiz maker. In addition, the participants felt the workshop provided new insights which currently pursued a never informed before.

The hot potato quiz maker was regarded as an interesting html-basis application to provide them new insights. As reveal in the survey, the teachers perceived it not only as the new experience practice but received as challenge. This is because the features and the function of the menu needs more practices and efforts to surf all functions in it. The responses of the respondents are presented in the following Table 1. 
Table 1. New insights perception toward the workshop

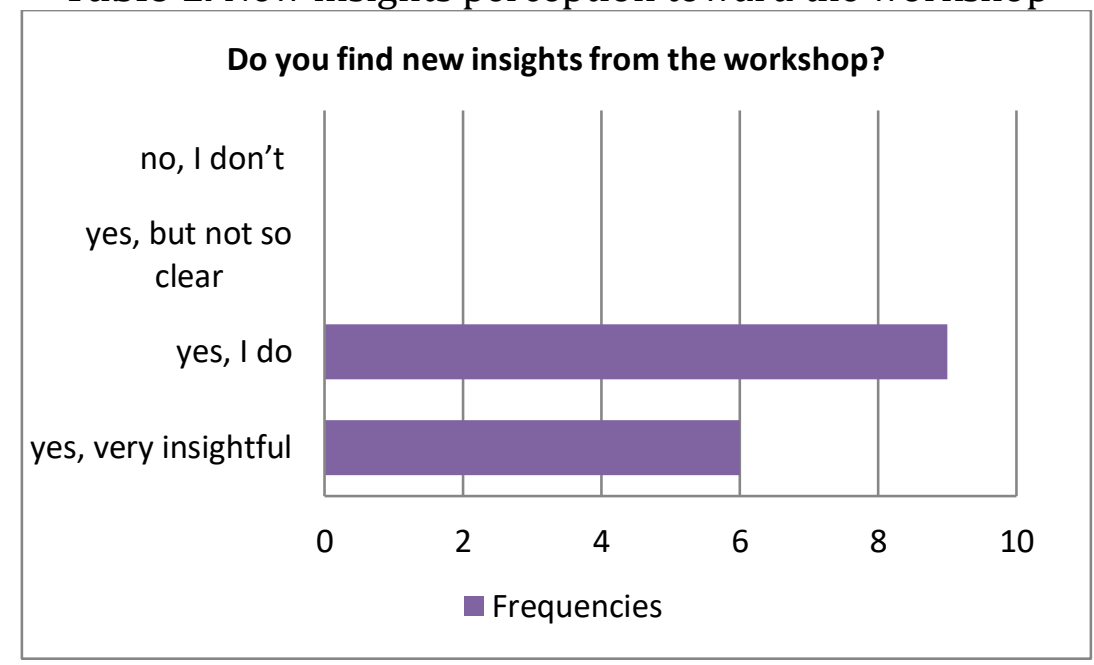

\section{Enthusiasm of all participants during the workshop}

During mentoring and practices, participants showed their enthusiasm and curiosity. Even the new normal procedures were addressed, alive and critical questionanswer sessions suggest their psychological condition. This is an indication the program was successful. The following samples of situation prove the situation of fun but full of learning engagement.
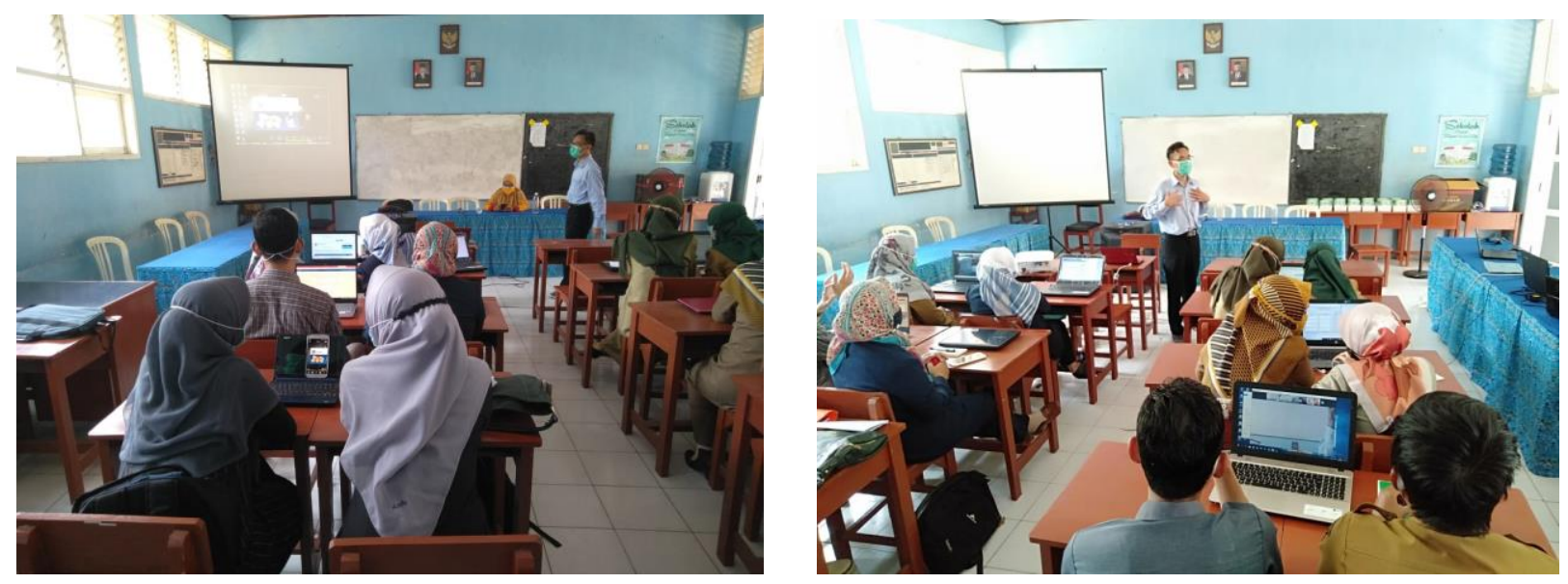

Figure 4. Workshop situation

\section{Emerging issues}

As the program lasted less than 8 hours, some issues emerged regarding the workshop to indicate the participants' high motivation to master the application discussed in the workshops. The asked more extended times and to have regular workshop relating to the new application to make their teaching more efficient and effective not only for today online learning but also to face the normal class. These responses are summarized in the following Table 2.

Table 2. Emerging issues during the workshop

\begin{tabular}{ccl}
\hline No. & Issue & \multicolumn{1}{c}{ Responses } \\
\hline 1 & Duration & Need extended time for assistantships \\
2 & Technical & Needs regular workshop \\
3 & Materials & Interesting and insightful \\
\hline
\end{tabular}




\section{Conclusion}

The workshop of android-based online quizzes had run successfully. This received positive responses from the participants. The evaluation also showed a positive impact on the understanding and ability of the participants.

\section{Acknowledgement}

This community service program is facilitated by financial support from the Institute of Community Service of Swadaya Gunung Jati University Cirebon throughout the 2020-2021 financial grant

\section{Referensi}

Aisyah, S., Danumihardja, M., \& Misdi, M. (2020, April). The Impacts of Cell Phone Usages on Learning Motivation: What Students Say?. In International Conference on Agriculture, Social Sciences, Education, Technology and Health (ICASSETH 2019) (pp. 203-204). Atlantis Press.

Misdi, M. (2020). E-PORTFOLIO AS AN AUTHENTIC LEARNING ASSESSMENT IN A RESPONSE TO COVID-19 OUTBREAK IN INDONESIAN HIGHER EDUCATION: TOWARD CRITICAL STUDENT-WRITERS. Research and Innovation in Language Learning, 3(2), 158-162.

Misdi, M. (2017). Empowerment in Madrasah: What English Teachers Have to Say. Academic Journal Perspective: Education, Language, and Literature, 5(1), 36-44.

Misdi, N., Kusriandi, W., \& Tambunan, A. R. S. (2020). Impact of ICT-assisted thesis writing on Student researchers' psychological empowerment: Indonesian case. In Journal of Physics: Conference Series (Vol. 1477, p. 042063).

Destiana, R. (2020, March). Portraying a web-driven lecturer: lesson learned from an Indonesian accounting class. In Journal of Physics: Conference Series (Vol. 1477, No. 5, p. 052039). IOP Publishing. 